ANI MANUKYAN

Associate Professor of the Chair of Foreign Language

Teaching Methodology, ASPU, PhD in Pedagogy

\title{
HOW TO TALK TO STUDENTS SO THEY LISTEN TO YOU
}

Think twice before you speak, because your words and influence will plant the seed of either success or failure in the mind of another.

Napoleon Hill

Words are powerful. They have the ability to inspire, motivate, and persuade; or discourage, dismiss, and dissuade. The right words show respect, gratitude, commitment and excellence.

It's important in teaching to choose your words wisely because they expose the number one ingredient to success: attitude. In the classroom, a positive collaborative mind-set can mean the difference between winning the love of your learners or losing it, developing teamwork or destroying trust, reaching your upmost objective or not.

As teachers we all know that our voice is a teacher's most valuable asset. Our words and tone of voice have a profound effect on students. By tuning in to the language we use with learners we can empower our students, helping them to learn new skills and become their best selves.

Key words and expressions: teacher's voice, behavior, audibility.

The one thing teachers do most often is talk. With talking they transmit not only information, but also mood, atmosphere and emotions. Moreover, how we speak and what our voice sounds like have a crucial impact on class. Harmer recommends three issues we should think about when considering the use of the voice in the management of teaching: audibility, variety and conservation /3:45-64/.

\section{- Audibility}

The teacher's voice needs to be effective in a variety of circumstances. Teach- ers need to be audible. Students at the back of the class must be able to hear them as well as those at the front. Switching from one-to-one and small groups to whole-class and games situations, teachers have to have adaptability as one of their abilities. Audibility, however, cannot be divorced from voice quality. Teachers need a voice which projects well and appropriately in all these circumstances and which is also pleasant to listen to. Teachers do not have to shout to be heard or to sound understandable. Good voice projection is more important than volume. Speaking too softly or unpleasantly loudly are both irritating and unhelpful for students. Expressive voices, used in an imaginative way, draw students in and make them want to pay attention and listen. If such a voice has quality and liveliness, they will be motivated to attend, participate and learn.

Just as teachers have to use their voices over long periods of time, so students are required to listen to, or at least hear, teachers' voices during class, the school week or semester. Meanwhile, the discomfort the teacher is experiencing is transmitted to students. They also feel uncomfortable and they lose confidence in the teacher and become disturbed. Unintentionally, disruptive behaviour may be the outcome. Teachers should avoid 'raising their voice' in the sense of shouting or using a higher pitch, since this itself, may have an even more disturbing effect on the group. As a result, 
learning and positive activity is no longer possible. Besides, shouting over the noise of the class is a sure way to get a sore throat.

When a voice is being badly used and abused in the classroom, this has negative effects on the students. A voice that is uncontrolled can often lead to misbehaviour. Students respond inappropriately when they feel that the teacher's voice is patronizing, too loud, monotone or weak. Bad behaviour can result from the lack of knowledge teachers have about the effect of their voice on their students.

\section{- Variety}

Harmer mentions that it is important for teachers to vary the quality of their voices and the volume they speak at, according to the type of lesson and the type of activity. The keyword is 'variety'. Our voices can be varied along a number of parameters: volume (how loud or softly we speak), pace (how quickly or slowly we speak, and how we use pausing), pitch (how high or low in our voice range we go), modulation (how we adjust the tone of our voice to convey a mood). If your voice is too high pitched, it can sometimes sound desperate, apologetic, and it seems as if you are asking students for permission when you are giving directions. The key to making the voice more interesting is to practice varying the above mentioned parameters. Remember that a tired voice can rarely be an interesting voice /3:45-64/.

\section{- Conservation}

The most common problem associated with the untrained voice is a lack of knowledge of good breathing habits. Breathing properly means being relaxed (in the shoulders, for example, and not slumped backwards or forwards), and using the lower abdomen to help expand the rib cage, thus filling the lungs with air. If breath is consistently only taken into the upper region of the lung, then the foundation support needed to expel the air will be insufficient.
This leads to constrictions in the throat that will inhibit the voice. This is a very frequent problem in teachers' voices.

Warm and expressive voices, used in an imaginative way, draw students in and make them want to pay attention and listen. If such a voice has quality and liveliness, they will be motivated to attend, participate and learn.

In order to motivate, inspire and persuade students, teachers should:

More often use the word 'you', than 'I'.

"When attempting to influence another's thinking, the words 'you' and 'your' are among the most persuasive words because they refer directly to the listener," DarlingHammond explains /1:13-16/. "Conversely, the self-centric pronouns which refer directly to the speaker are not as convincing: 'I,' 'Me,' 'My,' and 'Mine,' or 'We,' 'Us,' and 'Our,' which refer to the speaker's group or company." The frequent use of the word "you" answers the audience's unspoken question: "What's in it for me?" "The point is, whether it's a formal presentation or a casual conversation, avoid speaking from your perspective the whole time; choose words that directly address and include your listeners."

Use students' names.

"The most important word in any language is one's own name," Murray says /4:32-34/. "Your name carries a potent amount of emotion. When you make the effort to learn, remember and use another person's name appropriately, you not only convey to that person that he or she is important to you, you instill self-worth within them." In turn, they are likely to view you as a thoughtful caring person who listens well and pays attention to important details.

> Practice the three As: Appreciate, Acknowledge, Ask. 
Simple words that show a person they are valued generate positive emotions and create job satisfaction. "Taking the time to sincerely say to another, 'Thank you, I really appreciate your efforts,' or 'We couldn't have done it without you!' can really boost morale, Smith states /6: Forbes.com/."

Use a warm but professional tone.

A recess teacher tells a preschooler, "Ani, I noticed that you invited Karen into your game when you saw him standing alone. You really remembered our rule about including everyone!" By avoiding baby talk ("We're being so good today!") or overly sentimental language ("Honey, you're just the best little includer!"), she shows that she takes them seriously and sees them as competent and independent learners.

$>$ Convince with cause-and-effect phrases.

In persuasive or argumentative speaking, we try to convince others to agree with our facts, believe our claim, share our values, accept our conclusions, Smith says. "One proven approach to convince your audience is cause-and-effect reasoning. It's a method that helps your listeners see why things have happened or will happen as they do. It shows the inevitable linkage between what happens first and what happens next as a result.

\section{Make your expectations clear.}

Teachers should tell the class what they expect of them. What kind of contributions they want them to make in their field, and in the world. Being passionate and genuine is a great idea. Even avoid the "Some of You" speech ("Some of you will become lawyers, some of you doctors..etc"). Save the speech for one of the last classes you have with them (not the last class) and make it personal. For example: "David will find a cure for cancer, Areg will give Bill Gates a run for his money, ...”. Add a bit of humor and make sure it's obvious to the students that you have got to know something about every one of them.

$>$ Reinforce children's positive behaviors.

Reinforcing language identifies and affirms students' specific positive actions and encourages them to continue their appropriate behavior. For example, to a group that showed welcoming behavior toward one another at lunch, an adult might say, "I saw that you included everyone in your conversations. That helped make lunchtime pleasant for everyone at your table." With these words, the adult lets the children know that he noticed their positive behaviors. He also helps them see how they and their classmates benefited from those behaviors.

$>$ Use direct language.

Whether giving directions, noting positive behaviors, prompting children to remember rules, stopping misbehavior, or holding a discussion, it's important to use clear, direct language that is free of innuendo or sarcasm. With words, tone of voice, facial expression, and body posture, you can communicate calmness and respect. In this way, you'll avoid shaming and judging children, keep the focus on the positive behavior you want to see, and reduce the likelihood of power struggles.

Research has shown that using clear instructions and right chosen words help reduce violence, enhance cooperation and problem solving, and foster academic achievement. Teachers with social emotional competence develop supportive relationships with students, build on student strengths and abilities, establish behavioral guidelines, coach students through conflicts, encourage cooperation, and model respect and appropriate communication.

Students are more likely to be emotionally and intellectually invested in the class- 
es in which they have positive relationships with their teachers. Therefore, teachers who build positive relationships with their students may enjoy the following benefits:

- Increased levels of students' interested in and enjoyment of the class.

- Increased levels of students' academic achievement.

- A decrease in the occurrence of classroom disruptions /4:73-78/.

When asked how they evaluate instructors, students say that they value:

1. Presentations which are clear, understandable, and well organized;

2. Classes in which they feel that they have learned something of significance; and

3. Instructors who stimulate their interest in the course, encourage questions and discussion, are open to students' opinions, and are sensitive to students' concerns, confusions, and progress.

Effective teachers aren't boring. They grab students' attention, focus on problems and puzzles, and bring abstractions to life. They care about their audience, and are well-organized, clear, and expressive.
They also have a distinctive voice, which expresses their personality, approach, and style. Above all, they convey the excitement and the significance of their topic. They are effective speakers. Their teaching style reflects their personality /7: 35-43/.

Teacher trainings held in Armenia do not ensure skilful teacher-student interaction, in spite of the knowledge that understanding of human relations theories produces a positive change in teachers' attitudes and a corresponding positive change in classroom climate. There must also be paved a new type of teacher training that emphasizes the manner in which learning occurs. Equally important, this new type of training should focus on teachers' understanding of themselves and the ways in which their perspectives of a particular situation at a particular time may influence their various decisions and behaviour.

If Rudyard Kipling was right, words are the most powerful drug used by humanity, whether we use that drug to heal or harm lies in the power of the tongue.

Article submission date 06.02.14

\section{REFERNCES}

1. Darling-Hammond L., ed., Studies of Excellence in Teacher Education, Washington, DC: American Association of Colleges for Teacher Education, 2000.

2. Grissmer D., Nataraj S., Kirby D., Teacher Turnover and Teacher Quality, www.tcrecord. org/PrintContent.asp?ContentID=10381.

3. Harmer J., How to Teach English. An introduction to the practice of English language teaching, Pearson Education Limited, 2007.

4. Murray Ch., Supportive teacher-student relationships: Promoting the Social and Emotional Health of Early Adolescents with High Incidence Disabilities, Childhood Education 78.5: 285-290, 2000.

5. Phelan P., Davidson A., Locke H., Thanh C., Speaking up: Students' Perspectives on School, Phi Delta Kappan 73.9: 695-704, 1992.

6. Smith J., Words and Phrases that Inspire, Motivate and Persuade at work, Forbes.com, March 26, 2013.

7. Testerman J., Holding At-Risk Students: The Secret Is One-on-One, Phi Delta Kappan 77.5: 364-365, 1996. 


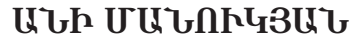

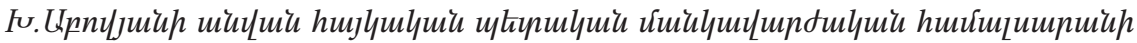

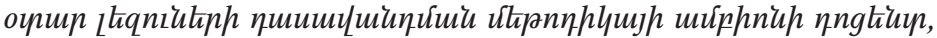

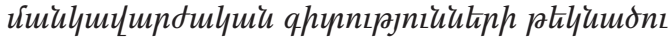

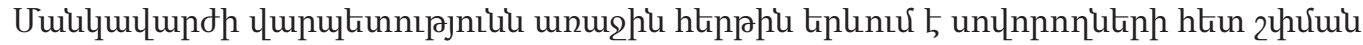

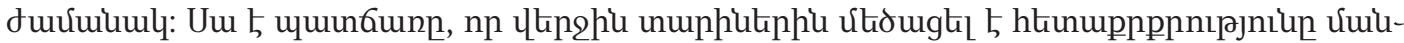

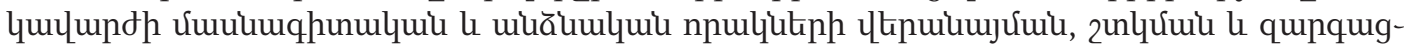

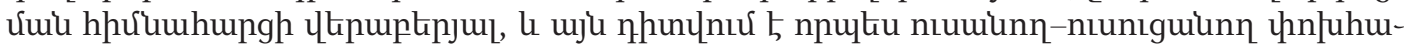

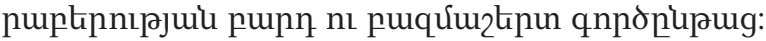

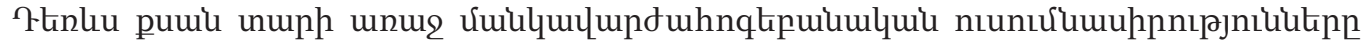

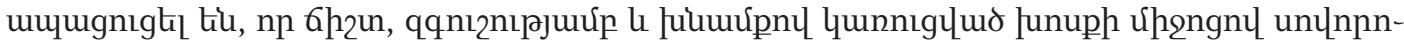

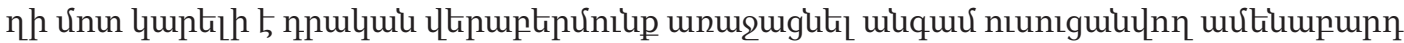

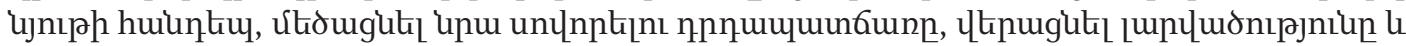

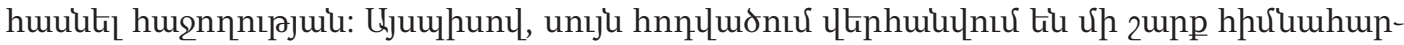

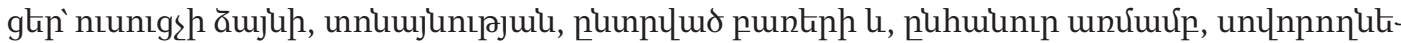

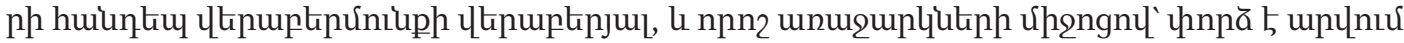

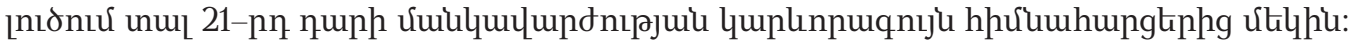

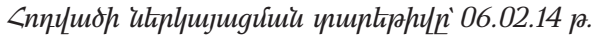

\section{КАК ОБЩАТЬСЯ СО СТУДЕНТАМИ, ЧТОБЫ ОНИ ТЕБЯ СЛУШАЛИ}

\author{
АНИ МАНУКЯН \\ Доцент кафедри методики обучения иностранным языкам Армянского \\ государственного педагогического университета имени Хачатура Абовяна, \\ кандидат педагогических наук
}

Мастерство педагога проявляется прежде всего в сфере его общения с учащимися. Именно поэтому в последние годы усилился интерес педагогической и психологической науки к проблеме педагогического общения как сложному многоаспектному процессу взаимодействия в системе «учитель- ученик». Важным аспектом данной проблемы является вопрос о влиянии стиля педагогического общения учителя на разные сферы учебной деятельности учеников, а в частности, на их мотивацию учения.

Еще 20 лет назад психолого-педагогическая наука убедительно доказала, что для того чтобы воспитание было эффективным, у ребенка необходимо вызвать положительное отношение к тому, что мы хотим в нем воспитать. А то или иное отношение всегда формируется в деятельности, через сложнейший механизм взаимоотношений, общения.

Педагогическое воздействие, как правило, соответствует целям и задачам, на которые ориентирован учитель. Если целью педагога является установление демократических отношений со своими учениками, то его воздействия не должны носить авторитарного характера, не должны оскорблять достоинства учащихся.

Педагогическое воздействие должно способствовать тому, чтобы, во-первых, инициировать активность ученика, поскольку только активная личность способна познать окружающий мир и развить свои задатки; во-вторых, помочь ученику овладеть способами организации деятельности и взаимодействия с миром, так как ученик не всегда знает, как решать учебные и тем более жизненные задачи; в-третьих, содействовать осмыслению «Я» ученика в его связях с окружающим миром, предоставить ему возможность самостоятельно принимать решения и самому нести за них ответственность. 